\title{
У ПОЛОНІ ПАРАДОКСУ
}

\author{
Г.А. Балута
}

Парадокс - це завжди проблема спостерігача.

$$
\text { Н. Луман }
$$

Відомо, що поруч з проблемою достовірності, однією із найбільш загадкових ділянок епістемології, є проблема «епістемологічної перспективи» чи оптимальної точки спостереження. Видатні чілійські природознавці, творці «коперніканської» філософської теорії Г. Матурана та Ф. Варела розглянули дискурс як процес аутопоезису (вихідної автономної позиції, на підставі якої ми здійснюємо опис). Визначення аутопоезису вийшло за межі природничих наук: існують системи, які визначаються здатністю виробництва компонентів, які рекурсивно генерують і реалізують сіть, яка відтворюе їх, та конституюють у просторі границі свого існування [8]. Звідси, кожен спостерігач спостерігає «власне спостереження». Цінність концепту аутопоезису виявилась у тому, що було визначено нову альтернативу епістемологічної генези, проблемної ділянки, залишеної у спадок німецькою класикою: у чілійських дослідників констатувалася біологічна природа розуміння (інтерпретації) світу завдяки відтворювальній здатності життєвих структур самого життя. Таким чином, реальність $є$ суб'єктивним концептом, наслідком організації живої істоти. Когнітивна система аутопоетичних систем залежить від аутопоетичних зв'язків (адаптації) на основі впорядковуючих принципів простоти і симетрії. Рефлексія (мова) як різновид такого зв' язку ніби огортає спостерігача, який спостерігає самого себе. Погодьмося, у філософській теорії елементи подібні зазначеним ідеям проступали в окремих підходах Ніцше, Фрейда,

Актуальні проблеми духовності

(Відп. ред.: Я.В. Шрамко)

Кривий Ріг (2007), 191-203 
Гуссерля, Хайдеггера, Платона - творця одного з перших антропологічних визначень, позбавлених філософського пафосу.

Авторам нової теорії вдалося по-новому поглянути на систему природа-людина, коли зв'язки між суб'єктом і об'єктом отримують вигляд живої динаміки, залежної як від біологічного типу, так і від соціальних структур. На думку дослідників, спостерігач у своєму досвіді не здатний розрізняти сприйняття та ілюзію. Вірогідність - це те, що дозволяє нам самозбереження, самовідтворення. Вихідною характеристикою аутопоезису стає рекурсивність - коло зворотного зв'язку, що можна розуміти як схему процесу самоутворення. Аутопоезисний механізм самовідтворює власну організацію. Існують різні шляхи адаптації i, таким чином, цінності - відносні. Отже, еволюція $є$ постійною підтримкою аутопоезису, яка проявляє себе у різних формах, в тому числі у людській культурі.

Тема аутопоезису була продовжена Н. Луманом, видатним теоретиком сучасності. Відмінність між поглядами Н. Лумана та творців аутопоезису полягає в генералізації Н. Луманом нового поняття, останній поширює теорію самореферентних систем на соціальні системи. Ідеї новаторів пронизані скепсисом відносно достатньої обгрунтованості знань як аутопоезисних концептів або ж рекурсивного відтворення аутопоезисної системи спостерігачем. «Але виникає питання: хто це спостерігач? Традиційно заведено вважати, що таким спостерігачем $\epsilon$ автор самого себе; нерідко у ролі такого спостерігача розглядають наукову спільноту або взагалі суспільний спосіб бачення», - відзначає О. Садоха, авторка перекладу складних колізій луманівської «Сфенографії [7, с.79]. Головним поняттям наукової теорії філософа є комунікація. За Луманом, реальність та суб'єктивність виникають у мові. У центрі уваги зазначеної статті проблема спостерігача та парадоксу, що виникає у ході спостереження. Звичайно, ми не ставимо за мету з'ясовувати біологічні механізми аутопоезису, хотілося б окреслити деякі міркування стосовно вищезазначеного розуміння знання як «відтворювальної «здатності структур самого життя», чи є рекурсивне коло зворотнього зв'язку замкненим завдяки біології, чи можливо у самій замкненості протікають процеси, керовані іншими законами, незалежними від біології. Вирішення цього питання ми спрямували у русло розгляду проблеми парадоксу, порушеної Н. Луманом.

Зазвичай проблема парадоксу є логічною проблемою. Поруч з цим, як вважає Н.Луман, виникають інші можливості- побачити у парадоксі проблематичні конструкції, які стимулюють перебудову знання. «Зорієнтована на плюралізм теорія бачить у парадоксальностях за- 
гальну вихідну проблему, яку заміщують у всі способи через відмінності («distinction») і яка водночас стає підставою побудови різних систем когнітивної комплексності, відкладення яких ми зрештою виявляємо як філософію» 4 , с. 84]. Рішення, які система уявляє як логічні, природні та необхідні, у результаті парадоксальностей виявляються творчими ерзац-рішеннями. Парадокс ніби поглинає нашу логіку. Депарадоксалізація, з точки зору Н.Лумана, вимагає розгляду не самого парадоксу, бо це $є$ не більше як можливість побачити відмінність як єдність чи форму відмінностей, а вимагає методу «спостереження за спостереженням». «Парадокс - це завжди проблема спостерігача, пише дослідник. - Хотілося зауважити, що якби саме буття було парадоксальним, то парадоксальним було б і це зауваження. Тому парадокси можна спостерігати, тільки коли спостерігаємо спостерігача, що випливає з перспективи, яку називають сьогодні кібернетикою другого порядку. Будь-який крок до повного опису, який може досягти повноти тільки якщо сам себе містить, виходить на цю проблему» $[4$, c. 85].

Більшість сучасних підходів підводять до світоглядної переорієнтації наукової картини світу, виходячи із загальних передумов «епістемологічного парадоксу»: ми застосовуємо наші базові поняття, не маючи їх реального розуміння. Вирішення базових епістемологічних проблем скероване у досить потужне міждисциплінарне русло філософського реалізму в орієнтаціях на природничі науки та біологічні чи фізичні закони або ж філософського ідеалізму, в якому стирається межа між релігійною та нерелігійною вірами та проблема істинності знань співпадає з проблемою істинності віри. У християнстві дійсна картина реальності тісно пов'язана з етичним вченням, вчинки особистості узгоджуються з їі розумінням справжнього стану справ та відмовою від стандартно-логічного розуміння речей, що ніби продиктоване почуттям здорового глузду. Власне і у філосософських науках розуміння раціональності також переосмислюється як пошук найменш хибних варіантів чи вибір найбільш оптимальних шляхів теоретичного рішення та практичної дії.

Отже, повертаючись до основної теми, згадаємо, що і біологічноконструктивні підходи не уникли парадоксу. Стосовно традиційно-філософської оцінки останнього в поглядах Лумана відчувається легке роздратування: справжній філософ не ховається від проблеми як це зробили Фреге та Рассел, елімінувавши парадокс з конструкцій формальних систем, а намагається вирішити те, що найбільше кидається в очі як виклик раціональності власних конструкцій. «Парадоксалі- 
зація цивілізації призвела не тільки до зцивілізованості парадоксу», відзначає філософ, не зраджуючи знаковому стилю, що потребує вельми обізнаного тлумача, готового до радикальних поворотів, іноді суперечливої, але оригінальної думки. Але справа не у формі: філософ ставить під сумнів креативну функцію парадоксальності, що особливо цінно у новаторському сенсі. Автор пропонуе низку продуктивних ідей: пізнання мусить складатися з виокремлення парадоксу, на якому грунтується; актуалізує категорію «відмінності», як засобу розв'язання парадоксу і виводить проблему на універсальний рівень соціальних систем i, зовсім несподівано, релігійної метафізики.

Нам здалося цікавим поглянути на факт парадоксу як загальної форми, що супроводжує наше «раціональне» мислення та повсякдення буття, виходячи з інтерсуб'єктивної перспективи релігійно-філософських систем.

Отже, ми не можемо впевнено констатувати, що мислення нами раціональності як конструктивної чи категорійної форми відповідає дійсності, оскільки визнаються такі її особливості: по-перше, «раціональність» спостерігача обертається «нераціональністю» - результатом погляду на неї (раціональність) з іншої перспективи (перспективи спостерігача другого порядку); по-друге, у перспективі «інтенційна активність» завжди приводила до приголомшливої нової якості, яка виникала у результаті «зняття» суб'єкт-об'єктної суперечності, що можна мислити як граничний епістемологічний досвід, який потребує нових і нових обгрунтувань; по-третє, згодом під «новим» ми з подивом вгадуємо ясні прикмети старого. За деякими оцінками, наша раціональність продиктована психологічною потребою прояснити світ впорядкованим і гармонійним. Таким чином, що ж $є$ дійсним, а не повторюваним? Така «діалектична логіка», у зрозумілому світлі представлена К. Поппером, притаманна i «еволюції раціональності» - нової перебудови світоглядної системи, яка не «витримує» конфлікту «перспектив». Чи є раціональна еволюція реальним, а не позірним просуванням далі, позаяк знання, що отримало статус «нового» завершується у черговому парадоксі, скасовується ним. Так виникає нова проблема: накопичення чи то версій чи то знань $з$ ледве вловимими горизонтами їх істинності. Парадокс у своїй ясній присутності пронизує філософію Сократа, I. Канта, Ф. Ніџше, З. Фрейда, Е. Гуссерля, М. Хайдеггера, К. Поппера і завжди супроводжує кардинальні або ж видатні ідеї навіть як критерій їх філософської чи наукової новизни. Чи не тому парадоксодин із вимірів генія, про що нам ненав'язливо повідомив геніальний російський поет. Взаємовключеність раціональності і парадоксу була 
продемонстрована М. Вебером у відомому «парадоксі раціональності»: «плекання раціональності» обертається «ірраціональною пригодою». Чи можна це явище розглядати як природню діалектику раціональності, прогресивну за своєю суттю? На думку В.Н. Поруса, «рух раціональності подібний до світла, в неї немає «маси спокою» [6, с. 103]. Автор оглядової статті «Чи є наука самоорганізаційною системою?» та нарису теорії наукової раціональності «Парадоксальна раціональність» констатує, що, по-перше, раціональність здійснюється у нескінченному процесі долань і відтворень власної парадоксальності, по-друге, парадокс раціональності є об'єктивним явищем, що виключає популярні на даний момент ідеї філософсько-методологічного плюралізму, які «погоджуються» 3 тим, що найбільш проблемною ділянкою залишається нормативно-критеріальний базис раціональності, що «не встигає» за критичною думкою. (Власне, бачимо як «логіка застосовує парадоксальності щодо маркірування логічно контрольованого простору» Н. Луман). У психоаналітичній літературі піднімалась думка про те, що раціональність є нетривіальним способом адаптації, проясненням нами себе i, у такий спосіб, реальності через логічні чи, точніше, приватно-логічні експлікації, у яких основою змісту є приватна схема причинно-наслідкового зв'язку. Конфлікт між внутрішнім і зовнішнім знімається завдяки раціоналізації, яка лягає в основу захисних механізмів. Особливо показовою у плані парадоксу є реактивні утворення: подавлення неприйнятного і заміна на протилежне.

В руслі зазначеного міркування згадаємо теоретичні спроби «зняття» парадоксу (неочевидного) шляхом славнозвісних редукцій, натомість виникав новий і новий парадокс. Кантіантське вчення про антиномії накреслює шлях розв'язання «феноменального» парадоксу збереженням причетності людини до іншого гіпотетичного світу. Коли розум осідають питання, нав'язані ним самим, він ніби «пропадає» в антиноміях, таким чином, необхідно вийти за межі розуму у сферу віри. Залишаючись заручником реальності, людина причетна і до світу свободи - єдиної дійсної цінності. Кант залишив нам багатозначну фразу, відкриту для інтерпретацій: «Мені довелося обмежити знання, щоб звільнити місце для віри».

Так, І.Кант говорить про віру релігійну, але ж і філософське знання конструюється на грунті віри, відштовхується від попереднього знання, що висвітлює проблему «укоріненості», тобто принципової відсутності «чистого знання», яким редукціям воно не підлягало б. Важливий аспект прихованих передумов і сприйнятих на віру аксіом відмічає Х. Ортега-і-Гассет: «Життя завжди здійснюється на основі чи 
виходячи із певних припущень, що слугують ніби грунтом, на який ми спираємося чи з якого ми виходимо, щоб жити. I це у всіх сферах: як у науці, так і у моралі, політиці», - пише він [5, с. 71]. Християнська думка вже давно відмітила цей факт у простому вигляді: людська думка спирається на аксіоми віри, щоб уникнути регреса у нескінченність. Важко заперечити, що відома ідея Декарта («cogito») таки спирається на прихований базис віри у реальність «я». що не вдалося редукувати.

Чи не можна думати про парадокс як сутність раціональності? Caме парадокс є умовою можливості логічних операцій як зовнішня форма чи каркас нашого мислення і це потрібно враховувати при побудові філософських та наукових теорій, прогностичних версій, реаліях повсякденності. I плідність такого підходу полягає в тому, що визначається нова можливість перебудувати форму наших знань і перейти до інших вимірів, що пролягають за межами емпіричного. На наш погяд, це скоріше «вгадування» і «нейтралізація» майбутнього парадоксу, коли ми ще не опинилися в ситуації глухого кута. Ми бачимо, що «луманівський парадокс» вбрано у одяг Горгон, одну з яких перемагає Персей, дивлячись на неї у віддзеркалення щита і опинившись тим самим ніби всередині самого парадоксу. Можна згадувати інші теми: між Скіллою і Харибдою, єдиних у своїй суті, від яких не можуть порятувати навіть боги, але ж врятувався Одісей?

Поглянемо, про що повідомляє нам сама назва, яка походить також із грецької. 3 одного боку, «несподіваний, дивний». Така форма набула розповсюдження у повсякденному вжитку, з іншого, можна припустити: «пара»- суміжність, відхилення, переміщення та «докса»думка чи гадка. Отже, парадокс розглядається тут як зміщення думки (реальності). Виходячи з вищезазначеного, припустимо цю загальну форму як граничну межу, що не виштовхується за межі нашого мислення (досвіду) незалежно від суб'єктивного опису чи внутрішнього змісту. У реальності це набуває вигляду інтервалів, що заміщують одне одного: від простого вибору, що конфігурує іншу ситуацію до масштабів цивілізаційних суперечностей. Ознаками парадоксу є невизначеність, полярність, циклічність (замкненість), бінарність (двоїстість суті), протистояння, нескінченність. За версією Лумана, ця дивна форма виникає внаслідок порушень онтологічного та етичного порядку. Так, випливають нові цілком «людиномірні» прикмети: незадоволеність своїм «почесним» місцем, мета досягнення власного стану, бешкетність, гордість, заздрість, перевага, амбіції, допитливість [4, с. 89]. До речі, зауважимо, що допитливість майже скрізь довершує перелік гріхів, незалежно від культурно-символічного релігійного типу. (Ми не 
впевнені у надто сміливих поворотах «культурної» метафізики філософа, але якраз поділяємо незначне контекстуальне зауваження про те, що разом зі спробою розв'язати парадоксальність виникає відмінність між добрим та злим, запрограмована релігією.) Очевидно, що парадокс має свої закони і розвивається за схемою негативної діалектики: одна якість переходить у іншу, що сприймається нами як раптовість, несподіваність, незвичність, тобто «зміна гадки». Тоді модель нашого спостереження, яка підсвідомо інтрополює загальну думку, нагадуватиме пісочний годинник, у якому протилежні точки однаково віддалені від центру (спостерігача). Інтенційна активність у одному напрямі (пересипання піску) імпліцитно вибудовує протилежний вектор (переставляння годинника). На мові метафор це можна уявити так: якщо ми спрямовуємо на щось свою свідомість, насправді ми повертаємося до нього спиною, чим доступнішою нам здається реальність, тим далі вона віддаляється від нас. Це нагадує обертання навколо осі з їі незмінними елементами, чи, навпаки, обертання самої осі, на перший погляд, незалежно від вибору перспективи та про це ми будемо говорити пізніше. (За К. Поппером, вибір вихідного пункту спостереження не грає ніякої ролі і легко піддається критиці чи корекції. У Н. Лумана парадоксальність робить неможливим визначення місце знаходження спостерігача). Начеб-то очевидно, що суттю парадокса $є$ замкненість, але ж вона $\epsilon$ i загрозою, руйнуванням нового відтворення. Але як бентежить його видима відкритість - «квадрат, що не має кутів». «Парадоксальний» грунт потребує розмикання: хибного у своїй суті рішення, яке розглядається нами як раціональне.

Парадокс ніби «вбудований» у повчальні історії про відомих з дитинства героїв: «Цар Едіп», «Попелюшка», «Золота рибка» та інші витвори людського генія. Ним наповнені алегорії про те, як Зло одягає личину Добра, його сутність виражена в ідеї та символіці зороастрійського (ніцшеанського) вічного повторення, у християнській метафорі «змії, що кусає себе за хвіст». «Хто копає яму, той сам впаде у неї»,застерігає християнська мудрість. Про це «зачароване коло» писали і східні мудреці:

- «Повернення до початку називається спокоєм, а спокій називається поверненням до сутності. Повернення до сутності називається постійністю. Знання постійності називається досягненням ясності, а незнання постійності приводить до зла» [2, с. 14].

- «Недосконале стає досконалим, криве прямим, порожнє наповненим, старе змінюється новим; прагнучи малого, досягаєш ба- 
гатого; прагнення отримати багато приведе до заблуджень» $[2$, c. 15].

- «Щоб дещо стиснути, необхідно розширити його. Щоб послабити, треба зміцнити його. Щоб знищити необхідно дати йому розквітнути» [2, с. 20].

• «Перетворення у протилежне є дія дао...»[2, с. 22].

• «Те, що спокійне, легко зберегти. Те, що не показало ознак, легко спрямувати. Те, що слабке, легко розділити» [2, с.29].

- «Правдиві слова схожі на свою протилежність» [2, с. 32].

- «Красиві слова не заслуговують на довіру. Добрий не красномовний. Красномовний не може бути добрим. Той, хто знає, не доводить» $[2$, с. 34$]$.

• «Хто думає що все знає, той нічого не знає» [2, с. 428].

- «Хто знає глибину свого просвітлення і залишається у незнанні, той стане прикладом для всього світу» [2, с.431].

- «Людина найвищої чистоти схожа на зневажену» [2, с. 434].

- «У великого прямокутника не видно кутів» [2, с.436].

- «Де лихо, там і щастя» $[2$, с. 442].

- «Все це називається то прихованим, то ясним» [2, с. 434].

Отже, східна картина світу розглядає його діалектику через суперечність найбільш загальних категорій: бінарність світу розкривається в індо-арійській парі Мітра-Варуна. Це струнка система протиставлень: благий-неблагий, правий-лівий, близький (внутрішній)далекий (зовнішній), східний-західний, сонячний-місячний, деннийнічний, вогонь-вода, видимий-невидимий, космос-хаос, колективнийіндивідуальний, соціальний-природній тощо. Китайська релігійно-філософська думка розглядає світ як закон боротьби та єдності Інь та Янь. Космологія даосизму нагадує теорію Анаксагора. Як і Лао-цзи, Анаксагор визнає, що видимий світ походить з обертальних рухів хаотичної матерії. Проте відмінністю між ними $є$ погляди на проблему 
початку цього руху. Породжені Дао, Інь і Янь - протилежні сили іманентні матерії і $\epsilon$ причиною їі руху. (За Анаксагором, хаотична матерія почала рухатись через вплив на неї нематеріальної сили). Числова містика Піфагора розглядає світ бінарності: парності та непарностіжіночого і чоловічого, злого та доброго, темного і світлого, в чому ясно відчуваються елементи східної світоглядної семантики. I справді, ми розподіляємо світ на чоловіче та жіноче, «плюс» та «мінус», уявляємо справедливе і несправедливе, добре та зле і це справді є ознакою «правильності» чи раціональності нашого мислення. Уявлення раціональності як «парадоксального протистояння» (притаманного парадоксу) не виходить за межі нашого колективного та приватного досвіду i $\epsilon$ конституційним горизонтом, загальною умовою процедури типізації або ж смислової реконструкції. (Власне, така закономірність була плідно обгрунтована у структуралістських підходах, які сприяли герменевтичному руху від інтерпретації до розуміння (глибинного змісту) шляхом встановлення структурних кореляцій між соціальними та семіотичними системами.)

Розглянемо як вирішується проблема парадоксу у більш зрілих релігійно-філософських системах, зокрема християнстві, яке визначає онтологічний каркас через категорії Добра і Зла. Буддійське світорозуміння відразу ж скасовує всі емпіричні форми реальності, в тому числі і мову (мовлення). Антитетичність західного мислення «спростовується» дискурсивною єдністю. Як відомо, буддизм звинувачує західну думку в надмірному узагальненні реальності, яке позбавляє її гармонійної цілості і приводить до віддалення від неї. Конкретність реальності протиставляється абстракції, що її спотворює. «Логіка зробила нас до такого ступеня рабами, що ми безумовно підпорядковуємося іiї законам. Наш розум з самого свого початку нашого свідомого життя привчається нами до найбільш строгої дисципліни логічного дуалізму, тягар якого нам ніяк не вдається скинути. Нам навіть ніколи в голову не приходило, що ми можемо звільнитися від тих ланцюгів, якими ми самі себе прикували. Нам і справді нічого навіть мріяти про досягнення дійсної свободи, поки ми не відокремимося від антитези «так» $\mathrm{i}$ «ні». Наша душа постійне прагне цієї свободи», - пише Д.Т. Судзукі $[1$, c. 282]. В буддизмі майже всі філософські категорії, зокрема етичні, мають абсолютний зміст. Зло (тришна) - буття, таким чином, доброонтологічна редукція, якщо таке висловлювання допустиме. Суб'єктоб'єктне протистояння (парадокс) знімається у найбільш радикальній формі: по ту сторону буття, по ту сторону добра і зла. Але ж чи ця редукція-насильство не $\epsilon$ вдалою, байдуже, що називається свободою, 
позаяк зберігає сам парадокс у незмінному вигляді.

Західна релігійна думка апелює до суміжності речей, на відміну від східного синкретизму, у якому синкретичною $\epsilon$ і сама віра - сприйняття реальності у $\dddot{1}$ неподільності. Віра розглядається як очевидне знання, що спирається на авторитетний текст Святого письма. Власне авторитетний текст і $€$ реальністю, що приймається чи не приймається нами як істинне.

Християнські містики (так само як і філософи античності) не поділяли ідею тотожності Добра і Зла, притаманну зороастрійцям, індуїстам чи гностикам, проголошуючи її глибокою єрессю. Зло ототожнюється з невизначеністю, парністю, мінливістю (розмитістю), темрявою, невідповідністю (несправедливістю), агресією на противагу визначеному, конкретному, світлому, справедливому, сутнісному. (В даному разі виникає особлива проблема: бінарність - зворотний бік єдності, яка породжує парадокс. У світі людському зло - це лукавство (невизначеність), на відміну від простоти і ясності. На жаль, сучасне суспільство недооцінює цю ідеальну якість. «Простота - одне 3 найбільших благ i чеснот людини, - пише Іоан Кронштадтський, - . . I твоя душа хай не двоїться на добро і зло» [3, с. 53].

Оманлива «відкритість» парадоксу пропонує вибір, узгоджений 3 ніби ясною логікою нашого раціо. Виявляється, «не-вибір» як оптимальна раціональна дія не руйнує, а укорінює «парадоксальний грунт». Показовим у цьому відношенні є релігійна історія. Стрий Заповіт онтологізує парадокс у формулі «око за око», однак лейтмотивом Нового Заповіту є любов до ближнього як єдина умова спасіння світу та християнської душі, показник духовної зрілості людини. Віра розмикає нескінченність парадоксу «око за око», оскільки перевищує раціональність нашого мислення (чини з іншим так, як чинять 3 тобою). Не можна служити одразу ж двом панам: протистояння добра і зла знімається свободою, вибором, позбавленим сумніву щодо правильності (раціональності) своїх дій, оскільки знання добра як загального онтологічного закону усвідомлюється прийняттям віри (лат. veritas істина). Суперечності ніби випробовують істинність нашої віри, віра протиставляється як онтологічна сутність життя: «Не говори: я відплачу за зло, покладайся на Господа і він збереже тебе». Християнство орієнтує людину до справжніх, а не «раціонально-справжніх» цінностей, до справжньої (справедливої) логіки нашого вибору, незважаючи на ірраціональність ситуаційного горизонту i, таким чином, скасовує «дурну нескінченність» руйнування. «Любов до ворогів» руйнує парадокс у його суті, до часу поки його ознаки не визріють знову. Звідси - 
святість миру. Чи не $є$ парадокс (протистояння) формою порядку, побудованого на відмінностях і водночас умовою важкого випробування - міцності нашої віри або ж незалежності від обставин, надиктованих природою. Обираючи те чи інше, ми відштовхуємося від парадоксу, що спрямовує наше життя та наше мислення. Згадаємо, що в суперечці народжується істина. В цьому проявляється креативна функція парадоксу, яка ніби зберігає принцип простоти і симетрії.

Чи поширюється така діалектика на інші «нейтральні» світоглядні системи? Ми можемо тільки зауважити, що різним світоглядним рівням притаманна своя внутрішня логіка, когерентність, система достовірностей. Єдине, що можна сказати у даному контексті з приводу істинності наших знань: по-перше, вони є результатом незалежності чи свободи спостерігача. Творець створив світ речей за близькими ж принципами, що і світ свободи. Це непросте питання на довгий час залишається відкритим.

Слід відзначити, що з зазначеного міркування випливає особлива роль поняття «незалежності» як внутрішньої якості об'єкта. Наприклад, у сучасних теоріях категорія «незалежність», яка виявляється передумовою діяльності та вибору людини, розглядається як внутрішня якість об'єктів. Якщо визнати, що ця категорія являє собою істотну у розумінні буття, то вона повинна проявлятися на всіх шаблях онтологічної структури. На думку ряду дослідників явища вірогідності (Ф.Бунге, Ф. Дайсон, Ю. Сачков), незалежність окремих систем проявляється у тій мірі, в якій їх властивості не визначаються зовнішніми обмеженнями. Матеріальні речі все більше розглядаються як власні сутності, обумовлені, але не повністю детерміновані оточуючим середовищем. Незалежність (часткове підпорядкування внутрішнім законам) виступає, як вважають вони, умовою розмаїття як основи еволюції. Зовнішні причини $\epsilon$ дієвими лише в тому ступені, у якому вони реалізують власну природу та внутрішні процеси речей. Таким чином, видима циклічність відтворюваності приховує інші закони, що $€$ основою максимальної розмаїтості чи передумовою до еволюції. Звідси випливає розуміння великої релігійної мети: любові до вього живого. Принцип максимальної розмаїтості діє як на духовному, так і на фізичному рівнях, що змушує нас замислитися над переглядом жорсткого природного детермінізму. То ж християнство не заперечує існування природніх законів, але вони не перевищують законів їх Творця. I саме тому зберігає скепсис щодо цінності емпіричних знань, їх пріоритетності перед законами вищого порядку. Релігійне знання ставить під сумнів безпечність прогресивного розвитку науки, наголошуючи на то- 
му, що світ повсякденності, не затьмарений логічними побудовами, і виступає єдиною очевидністю, даною людині.

Отже, суперечності пронизують наше життя: найкращий 3 людей стає жертвою, але зберігає віру як єдиний порятунок людства, а найгірший - зраджує його, замикаючи коло власного життя не-вірою. Християнство пропонує не уникання відмінностей, не протистояння чи розчинення, а спів-існування, спів-причетність, спів-працю, природного розвитку речей, керованих етикою, простих істин, закріплених у християнському символі «миру» - вихідного принципу єдності універсальності та унікальності. «Мир є цілість - здоров'я душі»,- відмічає християнський мислитель.

3 огляду на вищезазначене, раціональність визначається нами як хибна укоріненість. Раціональна етика близька за своїм змістом до етики релігійної, її можна мислити як не укорінену віру. Позбавлена укоріненості, мораль підлягала неодноразовим переглядам впритул аж до тих ідей, у яких цінність життя вступала у суперечність із цінністю самої моралі. Єдино можливою формою укоріненості (незалежності) $\epsilon$ віра. Чи мало б людське життя найпростіші форми соціальної організаціі, якщо розгорталося б суто у біологічному просторі, якою б досконалою чи розумною не була б біологія. Схоже, що знання або ж розпізнавання реальності вибудовується завдяки орієнтації у горизонті раціональності (логічного порядку речей) та у горизонті віри (буттєвого, етичного порядку речей). Розмаїтість явищ, які демонструє світ людини, виникає внаслідок взаємоперетину горизонтів внаслідок внутрішньої незалежності. У природніх процесах наявність внутрішньої динаміки внаслідок взаємодії зовнішніх та внутрішніх законів є базисним принципом буття складно організованих систем. На сучасному етапі значна кількість науковців визнають вихідну даність етичного по відношенню до раціонального.

\section{1 Бібліографія}

[1] Буддизм. Четыре благородных истины. - М.: ЗАО Изд-во ЭКСМО-Пресс; Харьков: Фолио, 2000.

[2] Дао: гармония мира.-М.: ЗАО Изд-во ЭКСМО-Пресс; Харьков: Изд-во Фолио, 2000.

[3] Иоанн Кронштадский. Моя жизнь во Христе.-М.: Изд-во P.S., 1990. 
[4] Луман Н. Сфенографія // Філософська думка. - 2003. - № 3.C. 81-98.

[5] Ортега-и-Гассет X. Что такое философия? - М., 1991.

[6] Порус В. Является ли наука самоорганизующейся системой // Вопросы философии. - 2006. - № 1.- С. 95-109.

[7] Садоха О. У перспективах спостереження // Філософська думка. -2003 . - № 3. - С. 74-81.

[8] Maturana H. Autopoiesis: A Theory of Living Organization. New York: North Holland, 1981. 